\title{
NPT: An Exclusive Proliferation Treaty
}

\author{
Maziyar Shokrani
}

\begin{abstract}
After devastating use of nuclear weapons in 1945, negotiations to put limitations on their proliferation and use began among the superpowers that resulted in conclusion of several treaties and agreements in this field. The 1968 Treaty on the Non-Proliferation of Nuclear Weapons (NPT) is considered as cornerstone among the international instruments on non-proliferation and application of safeguards. The terms of NPT mainly follows three purposes: nonproliferation, peaceful uses of nuclear energy and disarmament. In this paper, the author will discuss how did the Powers enjoy the terms of the treaty to ensure that there will be no more horizontal proliferation and how did they ignore other terms of the treaty i.e. disarmament, to maintain superiority over the world. Finally, the author conclude that the only way to achieve a nuclear-weapon-free-world which is desired by NPT is to observe its terms fully and by all member states without discrimination, expanding the coverage of its enforcement to non-members by means of international law, and negotiate a comprehensive treaty on banning possess, test, use and threat to use nuclear weapons.
\end{abstract}

Index Terms-NPT, nonproliferation, nuclear weapons, nuclear disarmament.

\section{DEVElopMent OF ATOMiC BomB}

The earliest warning about the vast destructive power of atomic bomb might be found in the enclosures of a letter to American President Franklin D. Roosevelt in 1939 when the physicists, Leo Szilard and Eugene Wigner warned the potential construction of "extremely powerful bombs of a new type" that was signed by Albert Einstein [1]. This letter also demonstrated its concern and fear that Germans work on uranium from Czechoslovakian mines that they already took over which apparently meant that they could construct atomic bomb first. After intensive scientific research through the socalled Manhattan Project, led by the United States with participation of the United Kingdom and Canada, finally the first atomic bomb was produced and successfully tested. Later the incapability of the League of Nations in exercising its power to stop the war and taking action under the Covenant of the League of Nations made the United States using the atomic bombs against civilians in order to put an end to the war by dropping them on Hiroshima (August 6, 1945) and three days later on Nagasaki (August 9, 1945) which were the only atomic bombs used against civilians in the history. This incident remains as the most controversial issue in the modern human's history and international law which led to the death of 150,000 to 246,000 people. The use of atomic bombs on Japan received great support from American people. Public opinion tolls taken shortly after the

Manuscript received September 3, 2013; revised November 30.

M. Shokrani is with the International Law at Xiamen University, Xiamen, P. R. China (e-mail: Maziyar.Shokrani@gmail.com). use of the weapons indicated eighty per cent support and ten per cent opposition. According to the tolls, one-quarter of the American public regretted that the surrender of Japan came so soon that only two atomic bombs could be used [2]. Soon, the Soviet Union started working on its arms program since the Hiroshima bombing shocked the world in general and, the Soviet Union in particular. Stalin said: "The balance has been broken. Build the bomb; it will remove the great danger from us" [3]. In August 1949 the Union Soviet and then in October 1952 the Great Britain conducted their first fission weapon tests and joined the nuclear club of three States. Less than one month after Britain tested its first nuclear bomb on October 3, 1952 (Hurricane) in Western Australia, United States tested Ivy Mike on November 1, 1952 in the Pacific Ocean and then Castle Bravo on March 1, 1954 at Marshall Islands. Then the Soviet Union tested the first fusion weapon on August 12, 1953 (Joe 4) in Kazakhstan and then the first staged thermonuclear weapon on November $22^{\text {nd }} 1955$ (RDS-1) again in Kazakhstan. It was the last test undergone before the establishment of the IAEA. So far most of the tests were conducted outside the main lands of the operators. The tests raised not only security questions but also a range of environmental issues. The superpowers continued proliferation of nuclear weapons from 1963 to 1975 when the nuclear arms race evolved without control and this process continued till the end of the cold war. Much later, in 1974,two cases brought to the International Court of Justice (ICJ) on nuclear test issues. In those cases (New Zealand $v$. France) and (Australia v. France), New Zealand and Australia requested the Court to declare France's atmospheric tests as illegal however the Court chose not to confront the issue of illegality [4].

\section{EVOLUTION OF NUCLEAR NONPROLIFERATION REGIME}

In January 1946, the United Nations General Assembly established the UN Atomic Energy Commission (UNAEC) by passing its first resolution [5]. The target of the UNAEC was to make proposals for the elimination of nuclear weapons and the use of nuclear energy for peaceful purposes under international control.

General Assembly's resolution 41 entitled the 'Great Charter of Disarmament', in conformity with Article 11 of the Charter, emphasized on the necessity of an early general regulation and reduction of armaments and armed forces. The role of Security Council in relation to disarmament was not denied:

"In pursuance of Article 11 of the Charter and with a view to strengthening international peace and security in conformity with the Purposes and Principles of the United Nations[...] The General Assembly recommends that the 
Security Council gives prompt consideration to formulating the practical measures, according to their priority, which are essential to provide for the general regulation and reduction of armament and armed forces will be generally observed by all participants and not unilaterally by only some of the participants..." [6].

Shortly after establishment of the UNAEC, on 14 June 1946, the United States submitted the so-called "Baruch Plan" to meet the purposes of UNAEC. The fact behind Baruch Plan was that in the postwar years, Americans were trying to keep their monopoly over atomic bombs. The Baruch Plan would have given the agency under jurisdiction of UNSC a monopoly to research about the ways to make nuclear explosive and power, free of veto and backed up by military force if necessary, to conduct inspections in other countries to make sure they were not building nuclear weapons. The United States, however, suggested that it would not surrender its weapons to the agency until inspectors were on duty in the Soviet Union and in other countries with nuclear potential. The suggestion was rejected by Soviet Union [7] In fact the Soviet Union was already developing its own nuclear arms program. With acceptance of the Soviet Union, perhaps the United States could turn over all its enriched uranium and its atomic weapons to the United Nations. The lesson from Baruch Plan is that understanding and cooperation between the States are necessary for concluding agreements on non-proliferation and disarmament issues. Although we can never be assured that the dream of a world without nuclear weapons could come true if the Soviet Union would accept the plan and cooperate with the United States; however, at least there could be the earlier efforts to build a non-proliferation regime. Furthermore, the law making mechanism of international law could prevent a larger number of States to build or become capable of building nuclear bomb.

After the bombing of Hiroshima and the undergone nuclear tests by United States, Soviet Union and Great Britain, the balance of power in the world entered a new phase. The devastating and strategic power of atomic bombs were now clear to all of the States and raised concerns to those countries who realized the necessity of developing bombs either for defensive or deterring reasons. The most important and helpful element for them was that there still was no express prohibition by international law to build and use a bomb.

At this stage where the world concerned about military use of atomic energy, Americans proposed their new plans for the forgotten side of this energy. "Atoms for peace" was the title of speech made by U.S. President Dwight D. Eisenhower to the General Assembly on December 8, 1953. In this speech President Eisenhower informed the UN General Assembly that he will submit to American Congress, with every expectations of approval, any such plan that mainly would encourage world-wide investigation into the most effective peace time uses of fissionable material and diminish the potential destructive power of the world's atomic stockpiles [8]. The language used in this speech was promising and comforting to a world which was terrified by horror of atomic bombings and the arms race between the two super powers. It was obvious that the main purpose of the speech was not to give any hope to non-nuclear and non-developed countries to have access to nuclear energy, but was to break the cold relations with the Soviet Union and offer a proposal to open cooperation and harmonization in the field of nuclear activities both peaceful and non-peaceful. Fifty years after the speech, President Eisenhower's granddaughter, Susan Eisenhower pointed out that "The 'Atoms for Peace' speech had a number of objectives, but its over arching goal was to propose a set of ideas, a number of strategy, which would call on the soviets in discussions on nuclear matters at a time when arms control talks had stalled" [9]. Although the speech was beginning of negotiations that several years later led to establishment of the International Atomic Energy Agency, the Soviet Union criticized it that states possessing nuclear weapons should stop proliferation and not wait for a global agreement: "The Soviet Union consistently struggles for the ban of atomic weapon and at the same time for a considerable reduction in all other types of armaments" [10]. The Soviet Union in his Note on Eisenhower proposal made the counter-proposal which can be considered the first efforts in the history of non-proliferation which seek a complete nuclear disarmament and, of course, is yet to be achieved. The counter-proposal reads: "The achieving of an international agreement on this question could be an important step on the road to the complete withdrawal from armaments of states of all atomic, hydrogen, and other weapons of mass extermination together with the establishment of a strictly international control which would insure the fulfillment of the agreement on the ban of the use of atomic energy for military ends" [10, p. 54].

During this period, the main achievements of the nations were establishment of Nuclear Weapon-Free Zones (NWFZ). The UN General Assembly resolution 3472 B (1975) defines an NWFZ as any zone recognized as such by the General Assembly of the United Nations, which any group of States, in the free exercises of their sovereignty, has established by virtue of a treaty or convention whereby:

- The statute of total absence of nuclear weapons to which the zone shall be subject, including the procedure for the delimitation of the zone, is defined;

- An international system of verification and control is established to guarantee compliance with the obligations deriving from that statute [11].

According to the above definition, States establish such zones in the free exercise of their sovereignty which means they voluntarily give up their right to develop nuclear weapon programs on a regional basis. It could be a great and appreciable contribution to peace and security of firstly a region, and, secondly the globe. But, still these treaties were unable to remove the danger of nuclear weapons from the world. It seems the purpose of such treaties were to limit number of nuclear weapon states which resulted in strengthening monopoly over nuclear weapons.

From 1963 to mid 1970s (Disarmament Decades) United Nations made a number of proposals for the purpose of general and complete disarmament; however, the unlawfulness of using nuclear weapons was never included in any multilateral treaties. The fact is that by the time, except Soviet Union, no other state in the nuclear arms club was interested in a ban on producing and using nuclear weapons. 
The Soviet Union submitted a draft convention to the United Nations in 1967 under which the parties would agree to refrain from using or threatening to use nuclear weapons. In the same year the General Assembly adopted the Soviet Union draft in resolution 2289 [12] however the Western powers rejected the Soviet draft convention. In fact, the Soviet Union introduced to the world a chance to eliminate nuclear weapons and the fear of using the bomb. That was a missed chance that will never come back for decades.

\section{NEGOTIATION THE NPT}

From the beginning of the nuclear age and detonating the first nuclear bombs, the risk and fear of several additional countries acquiring nuclear weapon were present. Several States areas showed their ambitions to develop nuclear arms programs. It's clear that it could have disastrous consequences if they extend their possibly acquired nuclear weapons in to the regional hostilities. It was assumed that there are two possible ways for acquiring nuclear weapons: first, building nuclear weapons through an indigenous research program and, second, transfer of nuclear weapons from those countries which already acquired nuclear weapons to those who did not yet developed the nuclear weapon or were not capable of doing so. To prohibit these two ways of acquiring nuclear weapons for those countries who had not yet built at least one nuclear bomb, became the main idea and foundations of drafting the NPT.

During late 1950s Ireland introduced resolutions in the General Assembly supporting a ban on international transfer of nuclear weapons. In 1961, a similar resolution was passed by General Assembly [13]. The distinction between nuclear weapon states and non-nuclear weapon states were appeared in these resolutions expressly. At the same day the General Assembly made another resolution [14] called upon all States and in particular upon the States at the time possessing nuclear weapons, to use their best endeavors to secure the conclusion of an international agreement containing provisions under which the nuclear States would undertake to refrain from relinquishing control of nuclear weapons and from transmitting the information necessary for their manufacture to States not possessing such weapons, and provisions under which States not possessing nuclear weapons would undertake not to manufacture or otherwise acquire control of such weapons.

The resolutions clearly shows that the negotiators of a non-proliferation treaty never desired a complete nuclear disarmament and just at max could go for giving up further proliferation and increasing number of nuclear weapons by those who possessed it at the time. Although finally a complete and gradual disarmament clause was finally included in NPT, however that clause was never observed seriously.

Right after China had its first explosion in 1965, and following to the vote of United Nations Commission [15], negotiations for a treaty on non-proliferation of nuclear weapons began. The Eighteen Nation Disarmament Committee (ENDC), which was an autonomous body outside the United Nations, devoted its major efforts to negotiate the NPT. The ENDC was made up of eight states from non-aligned movement, five states from Eastern bloc and five states from Western bloc including Brazil, Burma, Ethiopia, India, Mexico, Nigeria, Sweden, the United Arab Republic, the Soviet Union, Czechoslovakia, Poland, Romania, Bulgaria the United States, the United Kingdom, Canada, France, Italy which was a political composition of the United Nations in 1960s.

In the period that the ENDC was negotiating the terms of a nonproliferation treaty, eight countries formed a group what was known as the "group of eight" was including Brazil, Burma, Ethiopia, India, Mexico, Nigeria, Sweden and the United Arab Republic on the Committee sharing common views on disarmament issues. A series of Joint Memoranda describing such views in some detail were issued by that group. Well-explained by High Representative for Disarmament Affairs that "One such memorandum, dated 15 September 1965, stated that a "treaty on non-proliferation of nuclear weapons is not an end in itself but only a means to an end"-namely, the achievement of nuclear disarmament. Throughout these years, India's representative in the ENDC argued that a true non-proliferation treaty must cover both the improvement or expansion of existing arsenals (that is, vertical proliferation) and the spread of such weapons to additional states. That view was actively supported by the other members of the group of eight" [16].

On November 23, 1965, the General Assembly adopted resolution 2028 (XX) [17] on the basis of the Eight-States joint memorandum which included a call for the conclusion of a treaty on nuclear nonproliferation and asked the ENDC to assume and carry out this legal task. The General Assembly noted in the resolution with satisfaction the efforts of the eight-nation memorandum to achieve the solution of the problem of non-proliferation of nuclear weapons, as contained in their joint memorandum of 15 September 1965 The General Assembly urged all states to take all steps necessary for the early conclusion of a treaty to prevent the proliferation of nuclear weapons and called upon the ENDC to give urgent consideration to the question of nonproliferation of nuclear weapons and, to that end, to reconvene as early as possible with a view to negotiating an international treaty to prevent the proliferation of nuclear weapons based on the following main principles:

- The Treaty should be void of any loop-holes which might permit nuclear or non-nuclear Powers to proliferate, directly or indirectly, nuclear weapons in any form;

- The treaty should embody an acceptable balance of mutual responsibilities and obligations of the nuclear and non-nuclear Powers;

- The treaty should be a step towards the achievement of general and complete disarmament and, more particularly, nuclear disarmament;

- There should be acceptable and workable provisions to ensure the effectiveness of the treaty;

- Nothing in the treaty should adversely affect the right of any group of States to conclude regional treaties in order to ensure the total absence of nuclear weapons in their respective territories;

The above principles which were considered as the fundamental legal objectives of the treaty were all ignored in 
drafting the desired treaty on nonproliferation of nuclear weapons. The NPT finally lacked effectiveness to achieve a general and complete nuclear disarmament. It had loop-holes to allow some non-nuclear weapon states to undergo clandestine nuclear arms programs. Finally NPT could not maintain the balance of mutual responsibilities and obligations since it divided the member states into two categories with totally different obligations.

\section{ADOPTION OF THE NPT}

The draft treaty was finally submitted to the General Assembly on March 1, 1968. The draft was adopted by General Assembly on June 12, 1968 by a 95-4 vote with 21 abstentions. The NPT was opened to signature on July 1, 1978 and entered into force on March 5, 1970. NPT's articles I and II divide member states into two categories of Nuclear Weapon States (NWS) and Non-Nuclear Weapon States (NNWS). They read as:

"Each nuclear-weapon State Party to the Treaty undertakes not to transfer to any recipient whatsoever nuclear weapons or other nuclear explosive devices or control over such weapons or explosive devices directly, or indirectly; and not in any way to assist, encourage, or induce any non-nuclear-weapon State to manufacture or otherwise acquire nuclear weapons or other nuclear explosive devices, or control over such weapons or explosive devices" and, "Each non-nuclear-weapon State Party to the Treaty undertakes not to receive the transfer from any transferor whatsoever of nuclear weapons or other nuclear explosive devices or of control over such weapons or explosive devices directly, or indirectly; not to manufacture or otherwise acquire nuclear weapons or other nuclear explosive devices; and not to seek or receive any assistance in the manufacture of nuclear weapons or other nuclear explosive devices."

According to Articles I and II, different sets of obligations are undertaken by both NWS and NNWS where the discriminatory character of the NPT becomes clear. Receiving nuclear weapons or other explosive devices and manufacturing or otherwise acquiring such weapons or devices or seeking assistance to manufacture such devices is only prohibited to NNWS. Briefly speaking, according to Article I and II:

- Nuclear Weapon States are bound NOT to help non-nuclear weapon states acquire atomic weaponry and;

- Non-nuclear-weapon States agree NOT to pursue the acquisition or development of nuclear weapons.

Article IX of the NPT defines nuclear-weapon State as “... one which has manufactured and exploded a nuclear weapon or other nuclear explosive device prior to January 1, 1967." By categorizing the states into nuclear and non-nuclear, Article IX legitimizes the de facto status of those states which acquired nuclear weapons before January 1, 1967. Such kind of "legal discrimination" imposed by NPT against those countries which did not acquired nuclear weapons before that date raised a number of issues. It may the gives the impression to non-nuclear weapon states that that main reason that NPT was drafted was not really banning the spread of nuclear weapon or disarmament but to legitimize the nuclear hegemony and monopoly of few countries while prohibiting other states to acquire nuclear weapons. The demand of the non-nuclear weapon states to establish an effective direct and conditional legal link between their obligations to renounce the acquisition of nuclear weapon capabilities themselves, and the commitment of the nuclear weapon states to cease their nuclear arms race and achieve their nuclear disarmament, do not seem to have been legally recognized by the NPT. Indeed, the NPT did not succeed to create balanced legal obligation between the two categories of states. The treaty failed to embody an acceptable balance of mutual responsibilities and obligations between the nuclear and non-nuclear weapon states in relation to the ultimate goal of the nuclear disarmament of the nuclear powers (Art. VI) and the preservation of the status of the non-nuclear weapon states, on the basis of their legal obligations under Article II as compared to the obligations of the nuclear powers under Article IV, are at a legal disadvantage [18].

The nuclear-weapon states did their job well. Articles I and II were exactly what they needed to keep their own proliferation and, instead, stop the horizontal proliferation. It was their dream since the beginning of the nuclear arms age. But for non-nuclear-weapon states, the situation was quite different. The terms of the treaty were far away from their expectations. The treaty was supposed to be an instrument towards the immediate and general and complete disarmament. Even the treaty did not meet the security assurances. There was no obligation for nuclear weapon states to guarantee defending the non-nuclear weapon states against a potential nuclear attack and also there was no obligation not to attack the member states by nuclear weapons. Indeed later the world observed that the United Sates threatened a member state to use nuclear weapons against it. President Obama said in his declaration in April 2010: "The United Sates will pledge not to use nuclear weapons against most non-nuclear countries -no matter what they use against us- but keep all options on the table for nations like North Korea and Iran" [19].

Although the NPT strictly prohibits the horizontal proliferation, still some hopes were there for vertical nonproliferation. Article VI provides that: "Each of the Parties to the Treaty undertakes to pursue negotiations in good faith on effective measures relating to cessation of the nuclear arms race at an early date and to nuclear disarmament, and on a Treaty on general and complete disarmament under strict and effective international control". The terms of this Article are not on the basis of an immediate action but rather provide a gradual process without a timeline. As of today (more than forty years after entry into force of the NPT) still no serious action is made towards general and complete disarmament and so far the efforts to adopt a universal treaty to ban testing and use of nuclear weapons were all failed. Even the reason behind those incomplete efforts towards nonproliferation, as well-mentioned by Shaker, may be that those highly developed states had 'much to lose' and 'little to gain' by a nuclear war [20]. 


\section{Conclusions}

The destructive power of nuclear weapons, being able to destroy the physical integrity of our planet, has been witnessed historically. Most of the plans and proposals on non-proliferation of nuclear weapons didn't succeed due to lack of cooperation and mutual understanding among the Powers. NPT as the main instrument on nonproliferation of nuclear weapons failed to halt the spread of such weapons both horizontally and vertically and, so far, there is in neither customary nor conventional international law any comprehensive and universal prohibition of the threat to use or use of nuclear weapons [21]. Therefore not only nuclear weapon states will not have any benefit or obligation in giving up their nuclear ambitions, but also more countries will be encouraged to withdraw from the NPT and join the nuclear arms club and become a de facto nuclear-weapon State for either deterring or military purposes. To prevent further proliferation of nuclear weapons, as a primary step, the terms of NPT's article VI shall be implemented towards a universal and complete disarmament. Negotiations to draft and adopt a comprehensive treaty on banning possess, test, use and threat to use of nuclear weapons should be launched in an effective manner by exploiting fullest extent of political and legal capacities; perhaps it's not too late. Otherwise, the world may witness further withdrawals from the NPT.

\section{REFERENCES}

[1] Einstein's letter to President Roosevelt. (1939). [Online]. Available: http://www.atomicarchive.com/Docs/Begin/Einstein.shtml

[2] B. Barton, "Why the USA dropped atomic bombs on Japanese cities, towards a nuclear-weapon-free-world," in Proc. the Forty-Fifth Pugwash Conference on Science and World Affairs, World Scientific, Singapore,/New Jersey/London/Hong Kong, 1995, pp. 190-195.

[3] L. G. John, "We know now: Rethinking cold war history," Oxford, 1997, pp. 96.

[4] Nuclear Tests. (1974). Australia v. France. Judgment, I. C. J. Reports. [Online]. $\quad 253 . \quad$ Available: http://www.icj-cij.org/docket/files/58/6093.pdf; Nuclear Tests. (1974). New Zealand v. France. Judgment, I. C. J. Reports. [Online]. pp. 457. Available: http://www.icj-cij.org/docket/files/59/6159.pdf

[5] Establishment of a Commission to Deal with the Problems Raised by the Discovery of Atomic Energy. (24 Jan. 1946). [Online]. 1(I). Available: http://www.un.org/depts/dhl/resguide/r1_en.shtml

[6] Principles governing the general regulation and reduction of armaments. (14 Dec. 1946). [Online]. 41(I). Available: http://www.un.org/depts/dhl/resguide/r1_en.shtml
[7] B. George, "The nuclear nonproliferation treaty, history and current problems," Arms Control Today, December 2003.

[8] President Eisenhower's “Atoms for Peace” Speech, before the General Assembly of the United Nations on Peaceful Uses of Atomic Energy, December 8, 1953,

[9] E. Susan, "Atoms for peace plus 50," IAEA Bulletin, vol. 45, no. 2, 2003.

[10] Bulletin of the Atomic Scientists, Feb. 1945, vol. 10, iss. 2, pp. 46.

[11] Comprehensive study of the question of nuclear-weapon-free zones in all its aspects. (11 Dec. 1975). [Online]. 3472(XXX) [A-B]. Available: http://www.un.org/depts/dhl/resguide/r30_en.shtml

[12] Conclusion of a convention on the prohibition of the use of nuclear weapons. (08 Dec. 1967). [Online]. 2289(XXII). Available: http://www.un.org/depts/dhl/resguide/r22_en.shtml

[13] Question of disarmament. (04 Dec. 1961). [Online]. 1664(XVI). Available: http://www.un.org/depts/dhl/resguide/r16_en.shtml

[14] Prevention of the wider dissemination of nuclear weapons. (04 Dec. 1961). [Online]. 1665(XVI). Available: http://www.un.org/depts/dhl/resguide/r16_en.shtml

[15] Resolution DC/225. Adopted by the U.N. Disarmament Commission on June 15, $1965 . \quad$ Available: https://disarmament-library.un.org/UNODA/

[16] D. Sergio, "Towards a world free of nuclear weapons," presented at Conference Commemorating $20^{\text {th }}$ Anniversary of the Rajiv Gandhi Action Plan, Delhi, India, 2008.

[17] Non-proliferation of nuclear weapons. (19 Nov. 1965). [Online]. 2028(XX)

Available: http://www.un.org/depts/dhl/resguide/r20_en.shtml

[18] A. Haralambos, "Nuclear disarmament in international law," McFarland \& Company, Inc., Jefferson/North California/London, 2000, pp.48.

[19] Fox News. (April 06, 2010). [Online]. Available: http://www.foxnews.com/politics/2010/04/05/obama-limit-potential-u ses-nuclear-weapons/, accessed 07.04.2010.

[20] M. I. Shaker, "The nuclear non-proliferation treaty: origins and implementation 1959-1979," Oceana Publications, 1980, vol. 1, pp. 5.

[21] Legality of the Threat or Use of Nuclear Weapons. (1996). Advisory Opinion. I. C. J. Reports. [Online]. pp. 226. Available: http://www.icj-cij.org/docket/files/95/7495.pdf

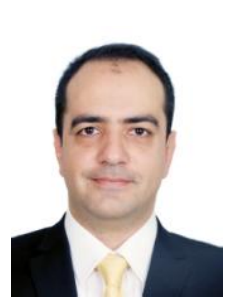

Maziyar Shokrani was born in Isfahan, a historica city in Iran. He pursued his bachelor in law at Isfahan University. Later he moved to India and obtained MCL at Delhi University and pursued the Ph.D. program in international law at Xiamen University. He has served as a lecturer at Islamic Azad University and worked as an adviser for several corporations; among them, Mobarakeh Steel Company is one of the largest state-owned manufacturers in Iran. His interested areas of international law include nuclear law, law of the sea and law of international organizations. Mr. Shokrani's first language is Persian, and is familiar with English, French, Arabic, and speaks some Chinese, Spanish and Russian. He was awarded the full scholarship by CSC (Chinese Scholarship Council) to further the Ph.D. program, and is expected to graduate in 2013 . 